IFN Working Paper No. 663, 2006

\title{
Cross-Border Acquisitions and Corporate Taxes: Efficiency and Tax Revenues
}

Pehr-Johan Norbäck, Lars Persson and Jonas Vlachos 


\title{
Cross-Border Acquisitions and Corporate Taxes: Efficiency and Tax Revenues
}

\author{
Pehr-Johan Norbäck, Lars Persson and Jonas Vlachos* \\ Research Institute of Industrial Economics
}

March 9, 2006

\begin{abstract}
We find that reduced foreign corporate taxes may lead to inefficient foreign acquisitions if complementarities between foreign and domestic assets are low, and to efficient foreign acquisitions if such complementarities are high. Moreover, with large complementarities, foreign acquisitions can increase domestic tax revenues. The reason is that in the bidding competition between the foreign firms, all benefits from the acquisition, including tax advantages and evaded taxes, are competed away and captured by the domestic seller which, in turn, pays capital gains tax on the proceeds. Technical issues in the tax code, such as the treatment of goodwill deductibility, is also shown to crucially affect the pattern of foreign acquisitions.
\end{abstract}

Keywords: Tax competition, Ownership, Tax revenues, FDI, M\&As. JEL classification: F23,

\footnotetext{
${ }^{*}$ We are grateful for helpful discussions with David Domeij, Rod Falvey, Mattias Ganslandt, Henrik Horn, Ulf Jakobsson, Søren Bo Nielsen, and participants in the International Mergers and Acquisitions Conference at University of Nottingham. Thanks also to Christina Lönnblad for improving the language. Financial support from the Marianne and Marcus Wallenberg Foundation, and Tom Hedelius' and Jan Wallander's Research Foundations, is gratefully acknowledged. Email: larsp@iui.se.
} 


\section{Introduction}

In the ongoing globalization process there is a concern among high tax countries that inefficient foreign owners with tax advantages will acquire domestic firms despite running them less efficiently. ${ }^{1}$ There is also a concern that foreign acquistions will lead to increased tax evasion and thereby to reduced domestic tax revenues. ${ }^{2}$

To address these issues, we develop an oligopoly model where inward FDI can take place both through foreign acquisitions and new investments, so-called greenfield entry. Acquired assets are in scarce supply and the acquisition price is determined in an auction acquisition game. Moreover, there is a complementarity between foreign and domestic assets that determines how efficiently a foreign owner will use the domestic assets. Inputs for greenfield entry are non-scarce and their (variable) price is constant. A domestic owner who keeps the domestic assets pays a profit tax on the profits and a capital gains tax on the remaining proceeds. If the domestic owner sells the assets, she/he pays a capital gains tax on the sales price. A foreign owner pays the domestic profit tax in the host country on the profits, unless transfer pricing is used in order to pay profit tax in the foreign country, and pays a capital gains tax in the foreign country. ${ }^{3}$

We start by establishing that in equilibrium both efficient and inefficient acquisitions may occur, where efficient acquisitions are mainly driven by the exploitation of high complemetarities between foreign and domestic assets, while inefficient acquisitions are mainly driven by the desire to eliminate a local rival. We then turn to the effect of reduced foreign corporate taxes on the equilibrium acquisition pattern.

First, we show that reduced foreign capital gains taxes will trigger foreign acquistions when goodwill associated with an acquisition is not deductible. The reason is that reduced

\footnotetext{
${ }^{1}$ See for instance the discussion in Henrekson and Jakobsson (2003).

${ }^{2}$ See for instance the discussion in World Investment Report (WIR) 1998.

${ }^{3}$ In many countries, such as the United States and many European countries, income from equity-financed corporate investment is taxed twice: at the corporate level, a tax is levied on net profits and at the shareholder level, dividends and realized capital gains on shares are subject to personal income tax. See Sørensen (1995).
} 
foreign capital gains taxes then increase the foreign owners' willingness to pay for domestic assets. To see this note that a foreign firm's willingness to pay for the domestic assets is then the product market profit for the acquired firm minus the profit the foreign owner would generate if it instead entered greenfield, net of domestic profit taxes and foreign capital gains taxes. A reduction in foreign capital gains taxes will then increase the foreign owner's willingness to pay and thereby increase the incentive for both efficiency enhancing and efficiency reducing foreign acquisitions. However, we also show that when goodwill is deductible foreign capital taxes will not affect the incentives for foreign acquisitions, since all costs associated with the acquisition are then deductible at the capital gain level.

Second, we show that reduced foreign profit taxes will trigger foreign acquistions when a foreign owner can use transfer pricing to transfer all profits to a foreign country with lower profit tax. ${ }^{4}$ A foreign firm's willingness to pay for the domestic assets is now the product market profit for the acquired firm minus the profit the foreign owner would generate if it instead entered greenfield, net of foreign profit taxes and foreign capital gains taxes. It then follows directly that foreign firms willingness to pay increases when foreign profit taxes are reduced. ${ }^{5}$

Next, we turn to the issue of how FDI affects domestic tax revenues. We then first establish that there is a fundamental difference between foreign direct entry investment in scarce and non-scarce assets as concerns the effects on tax revenues. When a foreign firm undertakes greenfield entry, it will pay a fixed entry cost only covering the opportunity cost in terms of factor inputs. No additional domestic capital gains are created, which is in contrast to acquisition entry, where an increase in taxable capital gains occurs due

\footnotetext{
${ }^{4}$ See Caves (1996) and the references therein for theoretical contributions to the literature on transfer pricing. Bartelsman and Beetsma (2000) find evidence of tax differences having a significant impact on where incomes are declared. See also references in World Investment Report (WIR) 1998.

${ }^{5}$ Indeed, the result that relatively low foreign tax rates can increase the attractiveness of domestic firms as targets for foreign merger activity is in line with some of the empirical findings in the literature. Auerbach and Hassett (1993), for example, find that FDI in the form of M\&A increased as a response to an increase in US corporate taxes.
} 
to the foreign takeover. To see this note that if the complementarity between foreign and domestic assets are sufficiently large, a surplus is created when the domestic assets are transferred to a foreign owner. However, due to the bidding competition between the foreign owners for buying these assets, the surplus is captured by the target firm, i.e. the domestic firm.

In particular, we demonstrate that a foreign acquisition can lead to increased domestic tax revenues, even if the foreign owner fully evades all taxes, since all benefits from the acquisition - including the value of tax evasion - are captured by the domestic sellers. ${ }^{6}$ The sellers end up paying more taxes, since the capital gain from selling is higher than the profit from keeping the assets. ${ }^{7}$

That the tax revenues generated by foreign acquisitions might be substantial is illustrated by the acquisition of the Swedish car producer Volvo by FORD in 1999. The stock price reactions to the acquisition process are shown in Figure 1.1. From the time that the first serious rumor emerged on December 181998 (Dagens Industri, December 22 1998) to the date when the acquisition was announced, January 28 1999, Volvo's stock market value increased by $21 \%$ more than the general index (SIXRX). Since $56 \%$ of the stocks in Volvo were owned by Swedes (Sundin and Sundqvist, 1998), future Swedish expected capital gains tax revenues were increased by 210 million Euro, which amounts to about ten percent of total net taxes on capital income in 1999. The motivation for this takeover premium is likely to be due to both synergies and tax savings. In December 2002, Volvo Cars (formerly Personvagnar), now an affiliate of FORD, was ruled to pay an additional tax of 196 million Euro, since the claimed deduction of royalties to the mother company FORD was denied by the local tax office (Dagens Industri, December 11 2002). Even if

\footnotetext{
${ }^{6}$ By now, it is a well established fact that most benefits from a takeover accrue to the owners of the target firm (Andrade et al., 2001). Regarding cross-border M\&As, it has been shown that there is a takeover premium in cross-border M\&As and that this premium differs between industries. See, for instance, Cebenoyan et al (1992), Dewenter (1995) and Harris and Ravenscraft (1991).

${ }^{7}$ Kant (1990) shows that transfer pricing can increase an MNE's global tax payment in a setting where MNEs pay both profit and export taxes.
} 


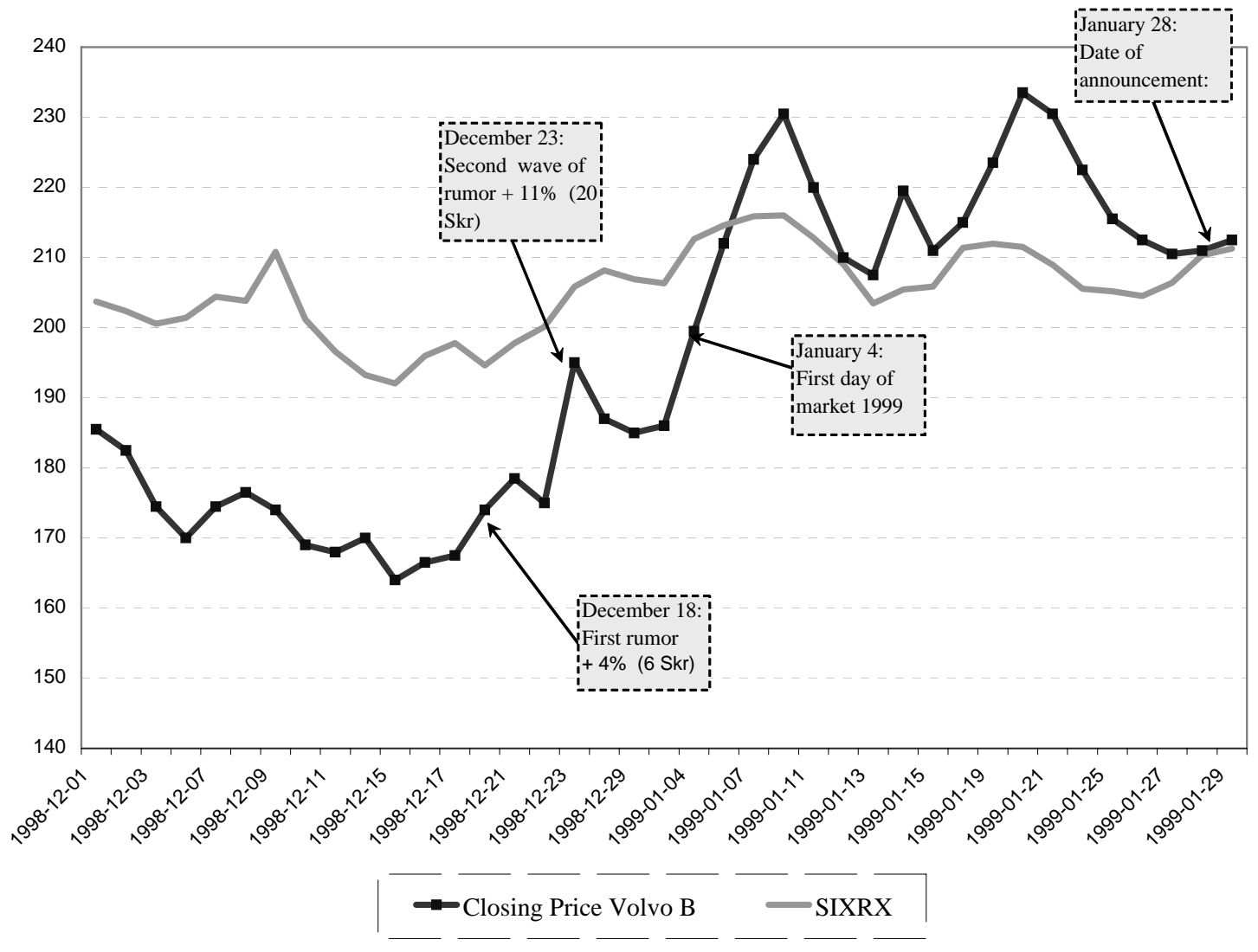

Figure 1.1: The stock price reactions to the acquisition of the Swedish car producer Volvo by FORD. 
these figures are just an indication, they suggest that the gains from "transfer pricing" were expected from the deal and therefore, at least to some extent, incorporated in the acquisition price. $^{8}$

The related theoretical literature on FDI and taxes is surveyed in Navaretti and Venables (2004). However, this literature does not explicitly address the tax effects of the different entry modes: greenfield, acquisition of assets already in the market or both. ${ }^{9}$ We add to this literature providing a model where foreign corporate taxes affects the entry mode. There is also a small theoretical literature addressing the welfare aspects of crossborder M\&As in international oligopoly markets. ${ }^{10}$ Our paper extends this literature by allowing foreign acquisitions to affect domestic tax revenues. The paper is also related to the literature on tax competition and FDI. ${ }^{11} 12$ We add to this literature allowing domestic asset prices to be affected by the foreign entry and foreign taxes. The features of the model developed should make it useful for analyzing issues where the focus is on the interplay between M\&A, firm investments and different types of corporate tax and subsidy policies.

The model is spelled out and solved in Section 2. Section 3, studies how foreign taxes affect the equilibrium ownership and ownership efficiency of the domestic assets. Section

${ }^{8}$ Since profit taxes are lower in Sweden than in the US, there are no direct profit tax benefits from this transfer. However, the IRS are known to be aggressive when it comes to taxing foreign profits and hence, the transfer was of value to FORD.

${ }^{9}$ See for instance,

Mattoo, Olarrega, and Saggi (2004) and Klimenko and Saggi (2005), and Norbäck and Persson (2005a, 2005b) for papers addressing welfare aspects and the choice of entry mode. However, none of these papers includes taxes.

10 This literature includes papers by, for example, Falvey (1998), Head and Reis (1997), Horn and Persson (2001), Lommerud, Straume and Sorgard (2005), Neary (2003), and Saggi and Yildiz (2005).

${ }^{11}$ See Wildasin and Wilson (1991) for an overview of the public finance literature on this topic. There is also an international trade literature on this topic; see, for instance, Fumagalli (2003) and Haufler and Wooton (1999).

12 There is a recent literature studying tax competition in environments where MNEs can use transfer pricing. See, for instance, Haufler and Schjelderup (2000) and Raimondos-Moller and Scharf (2002). However, to our knowledge, no paper in that literature allows foreign entry to affect domestic asset prices. 
4 examines the effects of foreign taxes on domestic tax revenues. Section 5 concludes. Finally, most proofs appear in the Appendix.

\section{The Model}

Consider a host country, $H$, where the market has previously been served by a single domestic firm, denoted $d$, possessing one unit of domestic assets, denoted $\bar{k}$. This market will now be exposed to international competition by an investment liberalization. There are $M$ symmetric foreign firms in the world market, which do not initially have any assets in Country $H$, but might now invest by an acquisition of firm $d$ or through investing greenfield in new assets in Country $\mathrm{H}$.

The interaction takes place in three stages. In stage 1, the foreign firms might acquire the domestic firm's assets. In stage 2, investment in new assets takes place in country H. In stage 3, product market interaction takes place and firms pay taxes on product market profits net incurred costs.

\subsection{Stage 3: product market interaction and tax payments}

We will work with the following notation: Let the set of firms in the industry be $i \in \mathcal{I}$, where $\mathcal{I}=\{d, 1,2, . . M\}$ and the set of (potential) ownerships of the domestic assets, $\bar{k}$, be $l \in \mathcal{L}$, where $\mathcal{L}=\{d, 1,2, . . M\}$. The asset ownership structure $\mathbf{K}=\left(k_{d}, k_{m_{1}, \ldots .}, k_{m_{M}}\right)$ specifies the asset ownership of each firm. The first entry refers to firm d's asset holdings, the second to foreign firm 1's assets holdings, etc.

In many countries, among them the United States and many European countries, income from equity-financed corporate investment is taxed twice: at the corporate level, a $\operatorname{tax}, t$, is levied on net profits, and at the shareholder level, dividends and realized capital gains are subject to a personal capital gains tax, $\tau .{ }^{13}$ Our formalization of the tax system corresponds to such a double taxation system. ${ }^{14}$ In order to capture the effects of corporate

\footnotetext{
${ }^{13}$ See Sørensen (1995).

${ }^{14}$ For a discussion of the Swedish system, see Lodin et al. 2001.
} 
taxes on the FDI pattern in a simple way, we work with the following taxation set up: A domestic owner keeping its assets $\bar{k}$ pays a profit tax, $t_{h}$, on the net profits and a capital gains tax, $\tau_{h}$, on the remaining proceeds. If selling the assets $\bar{k}$, the domestic owner pays a capital gains tax, $\tau_{h}$, on the sales price, $S$. A foreign owner of $\bar{k}$ and foreign firms entering greenfield pays the profit tax, $t_{r}$. If transfer pricing is possible, the profit tax is $\min \left(t_{h}, t_{f}\right)$. A foreign owner is then assumed to be able to shift profits to a location with lower profit tax without cost. ${ }^{15}$ If transfer pricing is not possible, the foreign firm pays the profit tax $t_{h}$ in the host country. A foreign owner always pays a capital gains tax, $\tau_{f}$, in a foreign country on the remaining proceeds. ${ }^{16}$

Let $\pi_{i}(\mathbf{x}, \boldsymbol{\kappa}, l)$ denote the pre-tax product market profit of firm $i$ net of investment costs for new assets, $\kappa_{i} . \mathbf{x}$ is the vector of actions taken by firms in the product market interaction, $\kappa$ is the vector of investments in new assets from stage 2 , and $l$ denotes the ownership of the domestic assets from stage 1. The optimal behavior in the product market interaction is given as follows. Given the investments in stage $2, \boldsymbol{\kappa}$, and the ownership of the domestic assets given from stage $1, l$, firm $i$ chooses an action $x_{i}$ (a price or a quantity) to maximize its net product market profit net of taxes and deductions for inputs and investment costs, denoted $\left(1-\tau_{r}\right)\left(1-t_{r}\right) \pi_{i}\left(x_{i}, x_{-i}: \boldsymbol{\kappa}, l\right)$ for $r=h, f$, where $x_{-i}$ is the set of actions taken by $i$ 's rivals. We assume there to exist a unique Nash-Equilibrium, $\mathbf{x}^{*}(\boldsymbol{\kappa}, l)$, defined as:

$$
\left(1-\tau_{r}\right)\left(1-t_{r}\right) \pi_{i}\left(x_{i}^{*}, x_{-i}^{*}: \boldsymbol{\kappa}, l\right) \geq\left(1-\tau_{r}\right)\left(1-t_{r}\right) \pi_{i}\left(x_{i}, x_{-i}^{*}: \boldsymbol{\kappa}, l\right), \quad \forall x_{i} \in R^{+}
$$

Since neither capital gains taxes $\tau_{r}$ nor profit taxes $t_{r}$ affect the firms' optimal actions $\mathbf{x}^{*}$ in (2.1), we can define a reduced-form product market profit for a firm $i$, taking as given the ownership $l$ of the domestic assets $\bar{k}$ and the vector of new investments $\boldsymbol{\kappa}$, as

\footnotetext{
${ }^{15}$ Costly transfer pricing will not qualitatively change the results. For an analysis where transfer pricing is endogenous within a setting where MNEs compete in an oligopoly, see, for instance, Nielsen et. al (2005).

${ }^{16}$ Note that profit taxes are assumed to be paid only where profits are reported. See Davies (2004) for an elaborate analysis on bilateral tax treaties.
} 
$\pi_{i}(\boldsymbol{\kappa}, l) \equiv \pi_{i}\left(x_{i}^{*}(\boldsymbol{\kappa}, l), x_{-i}^{*}(\boldsymbol{\kappa}, l), \boldsymbol{\kappa}, l\right)$. The reduced-form product market profit net of taxes is then simply $\left(1-\tau_{r}\right)\left(1-t_{r}\right) \pi_{i}(\boldsymbol{\kappa}, l)$.

\subsection{Stage 2: Investment in new assets}

In this stage, firm $i$ invests in new assets $\kappa_{i}$, such as capacity or R\&D, given the ownership $l$ of the domestic assets, $\bar{k}$, determined by the acquisition game in stage one. These investments are undertaken to maximize the reduced-form product market profits net of taxes and are assumed to be tax deductible. We assume there to exist a unique NashEquilibrium, $\boldsymbol{\kappa}^{*}(l)$, defined as:

$$
\left(1-\tau_{r}\right)\left(1-t_{r}\right) \pi_{i}\left(\kappa_{i}^{*}, \kappa_{-i}^{*}: l\right) \geq\left(1-\tau_{r}\right)\left(1-t_{r}\right) \pi_{i}\left(\kappa_{i}, \kappa_{-i}^{*}: l\right), \quad \forall \kappa_{i} \in R^{+} .
$$

Once more, since capital gains and profit taxes do not affect the firm's optimal actions $\boldsymbol{\kappa}^{*}$ defined in (2.1), this allows us to define $\left.\pi_{i}(l) \equiv \pi_{i}\left(\boldsymbol{\kappa}^{*}(l), l\right) \equiv \pi_{i}\left(\mathbf{x}^{*}\left(\boldsymbol{\kappa}^{*}(l)\right), \boldsymbol{\kappa}^{*}(l), l\right)\right)$ as a reduced-form gross profit function for firm $i$ under ownership $l$, encompassing the firm's optimal actions in period three, $\mathbf{x}^{*}$, and optimal investments in new assets in period two, $\boldsymbol{\kappa}^{*}$. The reduced-form product market profit net of taxes is hence $\left(1-t_{r}^{c}\right)\left(1-t_{h}\right) \pi_{i}(l)$.

The assumption that the foreign firms are symmetric before the acquisition takes place implies that we need only distinguish between domestic ownership $(l=d)$ and foreign (foreign firm) ownership $(l=m)$.

Definition 1. Let $\gamma(m)=\gamma>0$ be a measure of the complementarity between the domestic assets $\bar{k}$ and foreign firms' firm-specific assets.

Definition 1 implies that the "effective size" of the domestic assets $\bar{k}$ under foreign ownership is $\gamma \bar{k}$ (i.e. $\gamma(m)=\gamma>0$ and $\gamma(d) \equiv 1$ ). Since foreign firms are typically leading firms in their respective industries and possess firm-specific knowledge in terms of technology or know-how of organization of production and marketing (see Markusen (1995) and Caves (1995)), foreign ownership can result in a more efficient use of the local

asset, $\bar{k}$. This corresponds to a $\gamma$ larger than one in the model. We then make use of the following definition: 
Definition 2. An acquisition is efficient, if the buying foreign owner employs the local assets with a more efficient production technology, i.e. $\gamma>1$. An acquisition is inefficient if $\gamma<1$.

To proceed, we need to keep track of two different types of asset ownership structures. When the domestic asset $\bar{k}$ is sold to an acquiring foreign firm $(A)$, we have $\mathbf{K}(m)=$ $\left(0, \gamma \bar{k}+\kappa_{A}^{*}, \kappa_{G}^{*}, \ldots, \kappa_{G}^{*}\right)$. The acquiring foreign firm $A$ holds assets $\gamma \bar{k}+\kappa_{A}^{*}$, while the remaining $M-1$ greenfield entrants $(G)$ hold $\kappa_{G}^{*}$. If $\bar{k}$ is not sold and all foreign firms enter greenfield, we have $\mathbf{K}(d)=\left(\bar{k}+\kappa_{d}^{*}, \kappa_{G}^{*}, \ldots, \kappa_{G}^{*}\right)$, where the domestic firm $(d)$ holds assets $\bar{k}+\kappa_{d}^{*}$, and the $M$ foreign firms hold assets $\kappa_{G}^{*}$.

A change in ownership of existing domestic assets $\bar{k}$ from domestic to foreign ownership is then assumed to affect the (gross) reduced-form profit for firms of different types as follows:

Assumption 1: $\frac{d \pi_{A}(m)}{d \gamma}>0, \frac{d \pi_{G}(m)}{d \gamma}<0, \frac{d \pi_{h}(d)}{d \gamma} \equiv 0, h=\{d, G\}$

Assumption 1 states that an increase in the complementarity parameter, $\gamma$, increases the acquirer's profit, whereas the profit for a non-acquirer decreases. This assumption is compatible with several different investment and oligopoly models. One example is the Linear Quadratic Cournot Model presented in the Appendix, where an increase in complementarity has a direct effect on (the acquiring firm's) productivity, indirectly affecting firms' optimal actions in the stage-three product market game $\left(\mathbf{x}^{*}\right)$, or affecting these actions through firms' investment in new assets in stage two $\left(\boldsymbol{\kappa}^{*}\right) \cdot{ }^{17}$ Finally, for expositional reasons, we restrict the size of the complementarities to $\gamma \in\left[0, \gamma^{\max }\right)$, where $\gamma^{\max }$ is defined from $\left.\pi_{G}(m)\right|_{\gamma=\gamma_{\max }}=0 .{ }^{18}$

\footnotetext{
${ }^{17}$ This is an extended version, by an acquisition stage, of the model presented by Neary (2002).

${ }^{18}$ Endogenizing the number of greenfield entrants is tedious but straighforward and will not qualitatively affect results.
} 


\subsection{Stage 1: The acquisition game}

The acquisition process is depicted as an auction where the foreign firms simultaneously post bids and the domestic firm then either accepts or rejects these bids. Each foreign firm announces a bid, $b_{i}$. Following the announcement of bids, the domestic firm is either sold at the bid price or remains in the ownership of firm $d$. The acquisition is solved for Nash equilibria in undominated pure strategies.

\section{Ownership efficiency}

We here examine the effects of how reductions in foreign taxes affect the likelihood of inefficient foreign acquisitions, i.e. acquisitions where $\gamma \in(0,1)$ and the likelihood of efficient foreign acquisitions, i.e. acquisitions where $\gamma \in\left(1, \gamma^{\max }\right)$. We will show that whether reductions in foreign corporate taxes induce inefficient/efficient foreign acquisitions crucially depends on the level of complementarity between foreign and domestic assets, how the deductibility of "goodwill" associated with an acquisition is treated and whether transfer pricing is an option.

\subsection{Goodwill not deductible and transfer pricing not an option}

We start with the case that goodwill associated with the acquisition is not deductible and that foreign firms cannot make use of transfer pricing to avoid paying profit taxes in the host country. To solve the acquisition game, it will be useful to define $\Delta_{d}(S)$ as the net gain for firm $d$ of selling its assets $\bar{k}$ at a selling price $S$ :

$$
\Delta_{d}(S)=\underbrace{\left(1-\tau_{h}\right) S}_{\text {Net profit from sale }}-\underbrace{\left(1-\tau_{h}\right)\left(1-t_{h}\right) \pi_{d}(d)}_{\text {Net profit from no sale }} .
$$

From (3.1), let the reservation price of firm $d$ be $v_{d}=\min S$, s.t $\Delta_{d}(S) \geq 0$. That is, $v_{d}$ is the minimum price $S$ at which $d$ is willing to sell. Solving for $\Delta_{d}(S)=0$, we have:

$$
v_{d}=\left(1-t_{h}\right) \pi_{d}(d) .
$$


Note that the capital gains tax $\tau_{h}$ in the host country does not affect firm $d$ 's reservation price $v_{d}$, since from (3.1), the capital gains tax is levied on both the alternatives to sell and keep the assets $\bar{k}$, respectively.

Deriving the foreign firms' valuations is slightly more involved. Let $\Delta_{m l}(S)$ for $l=d, m$ be the net gain for an foreign firm from acquiring the domestic firm's assets at a certain price $S$ :

$$
\Delta_{m l}(S)=\underbrace{\left(1-\tau_{f}\right)\left(1-t_{h}\right) \pi_{A}(m)-S}_{\text {Net profit from acquisition }}-\underbrace{\left(1-\tau_{f}\right)\left(1-t_{h}\right) \pi_{G}(l)}_{\text {Net profit from not acquiring }} .
$$

Note that when not acquiring the domestic assets $\bar{k}$, these would either remain in the hands of the domestic firm $(l=d)$, or be acquired by a rival foreign firm $(l=m)$ in which case the foreign firm enters Greenfield. From (3.3), we can define an foreign firm's valuation as $v_{m l} \equiv \max S$, s.t $\Delta_{m l}(S) \geq 0$. Solving for $\Delta_{m l}(S)=0, v_{m l}=$ $\left(1-\tau_{f}\right)\left(1-t_{h}\right)\left[\pi_{A}(m)-\pi_{G}(l)\right]$ is thus the maximum price $S$ at which the foreign firm is willing to buy the domestic assets. Foreign firms thus have two valuations: The first is a takeover valuation which is an foreign firm's value of acquiring the domestic assets when these would otherwise remain in the hands of the domestic firm:

$$
v_{m d}=\left(1-\tau_{f}\right)\left(1-t_{h}\right)\left[\pi_{A}(m)-\pi_{G}(d)\right] .
$$

The second is a preemptive valuation, which is the foreign firm's value of acquiring the domestic assets when a rival foreign firm would otherwise obtain them:

$$
v_{m m}=\left(1-\tau_{f}\right)\left(1-t_{h}\right)\left[\pi_{A}(m)-\pi_{G}(m)\right] .
$$

Comparing (3.4) and (3.5), note that the net profit for $i$ of not obtaining assets $\bar{k}$ is different, due to the change of identity of the firm which would otherwise obtain the assets.

We can then use these net gains and valuations to derive the equilibrium bidding behavior and the equilibrium ownership structures. To simplify the presentation, we make use of the following assumption: 
Assumption 2: (i) There exists a $\gamma^{T}>0$ defined from $v_{m d}\left(\gamma^{T}, \cdot\right)=v_{d}$ and (ii) a $\gamma^{P}>0$ defined from $v_{m m}\left(\gamma^{*}, \cdot\right)=v_{d}$. Then, (iii) $\gamma^{\max }>\gamma^{P}>\gamma^{T}>0$ holds.

Assumption 2 ensures that all types of equilibrium ownership structures arise when varying the complementarity, $\gamma$. We can then state the following Proposition ${ }^{19}$ :

Proposition 1. Given that the complementarities between foreign firms' firm-specific assets and the domestic assets are: (i) sufficiently low, $\gamma \in\left(0, \gamma^{T}\right)$, no acquisition will take place and the EOS is $\mathbf{K}(d)$, (ii) of intermediate size, $\gamma \in\left[\gamma^{T}, \gamma^{P}\right.$ ), a foreign takeover acquisition will take place with $S^{*}=v_{d}=\left(1-t_{h}\right) \pi_{d}(d)$ and the EOS is $\mathbf{K}(m)$, and (iii) sufficiently high, $\gamma \in\left[\gamma^{P}, \gamma^{\max }\right)$, a foreign preemptive acquisition will take place with $S^{*}=v_{m m}=\left(1-\tau_{f}\right)\left(1-t_{h}\right)\left[\pi_{A}(m)-\pi_{G}(m)\right]$ and the EOS is $\mathbf{K}(m)$.

Proposition 1 is illustrated in Figure 3.1. In Figures 3.1 (i) and 3.1 (ii), we derive the equilibrium ownership structure (EOS) varying the size of the complementarities $\gamma$ for given taxes. In Figure 3.1 (iii), we explore how the EOS change when the foreign capital gains $\operatorname{tax} \tau_{f}$ varies.

Start with Figure 3.1(i). When complementarities are low $\gamma \in\left(0, \gamma^{T}\right)$, an foreign firm's takeover valuation is lower than the domestic firm's reservation price. This is illustrated in Figure 3.1 (i) where the $v_{d}$ curve is above the $v_{m d}$ curve. In this case, the combined profit of the acquiring foreign firm and the domestic target firm is lower than their stand-alone profits. Thus, without sufficient efficiency gains for the acquirer, the associated increase in concentration is not enough to make an acquisition profitable.

A foreign acquisition will occur for sufficiently large complementarities between foreign firms' assets and domestic assets. From Assumption 1, the takeover valuation, $v_{m d}=$ $\left(1-\tau_{f}\right)\left(1-t_{h}\right)\left[\pi_{A}(m)-\pi_{G}(d)\right]$, increases in the complementarity $\gamma$, since the expected

\footnotetext{
${ }^{19}$ Assumption 2 ensures that foreign acquisitions at reservation price $v_{d}$ emerge in equilibrium, but otherwise have no qualitative effect on the results. We refer to the Appendix for a full proof of the EOS relaxing Assumption 2.
} 


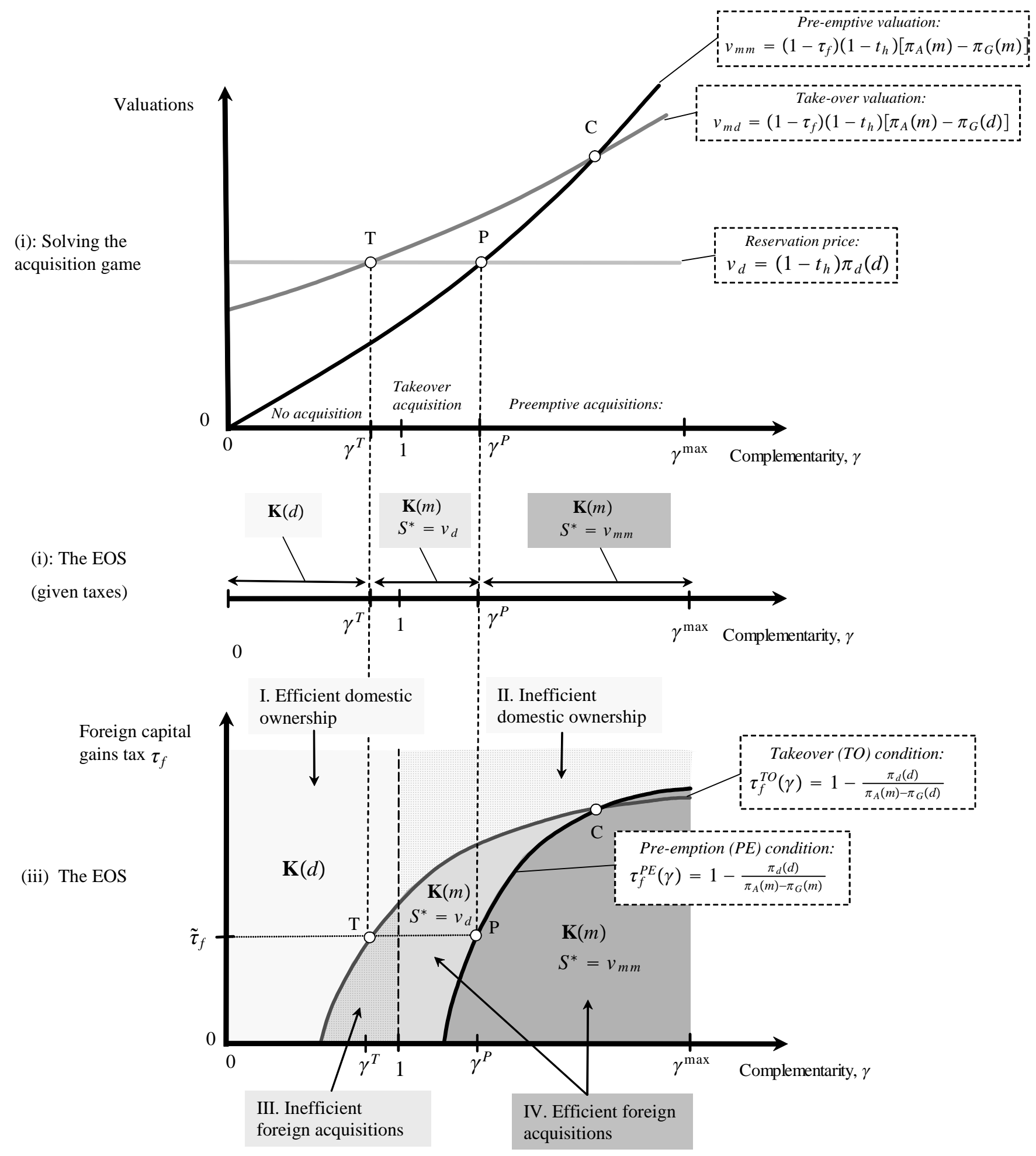

Figure 3.1: Solving for the Equilibrium Ownership Structure (EOS). 
profit as an acquirer $\pi_{A}(m)$ increases in $\gamma$, whereas the domestic firm's valuation, $v_{d}$, and the foreign firm's profit as a non-acquirer $\pi_{G}(d)$ are independent of $\gamma$. Assumption 2 states that at $\gamma=\gamma^{T}, v_{m d}=v_{d}$ holds. It thus follows that a further increase in complementarities $\gamma$ will make a takeover acquisition strictly profitable as $v_{m d}>v_{d}$ and the equilibrium sales price is then $S^{*}=v_{d}=\left(1-t_{h}\right) \pi_{d}(d)$. This is illustrated at point $\mathrm{T}$ in Figure 3.1 (i). ${ }^{20}$ Note that other foreign firms will not preempt a rival acquisition in this region, since a rival firm is better off as a non-acquirer due to the benefit from a more concentrated market, as shown by $v_{d}>v_{m m} \cdot{ }^{21}$

Finally, turn to the case with high levels of complementarity between foreign firms' assets and domestic assets $\gamma \in\left[\gamma^{P}, \gamma^{\max }\right)$. Using Assumption 1, we can note that an foreign firm's preemptive valuation $v_{m m}$ will increase more than the takeover valuation $v_{m d}$ since increasing complementarities do not only increase the product market profit as an acquirer but also decrease the product market profit as a non-acquirer:

$$
\begin{aligned}
\frac{d v_{m m}}{d \gamma} & =\left(1-\tau_{f}\right)\left(1-t_{h}\right)\left[\frac{d \pi_{A}(m)}{d \gamma}-\frac{d \pi_{G}(m)}{d \gamma} \begin{array}{c}
(+) \\
(+)
\end{array}\right] \\
& >\left(1-\tau_{f}\right)\left(1-t_{h}\right) \frac{d \pi_{A}(m)}{d \gamma}=\frac{d v_{m d}}{d \gamma} .
\end{aligned}
$$

Thus, the preemptive valuation $v_{m m}$ is not only driven by the benefits of obtaining a strong position in the product market as an acquirer, but also by the preemptive motive for avoiding a weak position as a non-acquirer. Assumption 2 states that at $\gamma=\gamma^{P}$, $v_{m m}=v_{d}$. From (3.6), it then follows that a further increase in complementarities into the region $\gamma \in\left(\gamma^{P}, \gamma^{\max }\right)$ will make a preemptive acquisition strictly profitable as $v_{m m}>v_{d}$. Fierce bidding competition among foreign firms then drives the equilibrium sales price to $S^{*}=v_{m m}=\left(1-\tau_{f}\right)\left(1-t_{h}\right)\left[\pi_{A}(m)-\pi_{G}(m)\right]$. This is illustrated by point $\mathrm{P}$ in Figure 3.1 (i). ${ }^{22}$. This completes the proof of Proposition 1.

\footnotetext{
${ }^{20}$ From (3.1) and (3.3), it follows that $\Delta_{d}\left(v_{d}\right)=0$ and $\Delta_{m d}\left(v_{d}\right)>0$ for $\gamma \in\left[\gamma^{T}, \gamma^{P}\right)$.

${ }^{21}$ From (3.3), it follows that $\Delta_{m m}\left(v_{d}\right)<0$ for $\gamma \in\left[\gamma^{T}, \gamma^{P}\right)$.

${ }^{22}$ From (3.3), it follows that $\Delta_{m m}\left(v_{d}\right)>0$ for $\gamma \in\left[\gamma^{P}, \gamma^{\max }\right)$. At $S^{*}=v_{m m}, \Delta_{m m}\left(v_{m m}\right)=0$.
} 
Let us now explore how changes in foreign corporate taxation influence the equilibrium ownership structure. Note from Figure 3.1 (i) that a takeover acquisition is just profitable at point T, where $v_{m d}=v_{d}$ holds. From (3.2) and (3.4), we can then solve for the level of foreign capital gains tax $\tau_{f}$ at which a takeover acquisition is just profitable:

$$
\tau_{f}^{T O}(\gamma)=1-\frac{\pi_{d}(d)}{\pi_{A}(m)-\pi_{G}(d)}
$$

We label this condition the takeover condition (TO-condition), $\tau_{f}^{T O}(\gamma)$.

In the same vein, we can define the preemption condition (PE-condition) $\tau_{f}^{P}(\gamma)$ as the level of foreign capital gains tax at which a preemptive acquisition is just profitable:

$$
\tau_{f}^{P E}(\gamma)=1-\frac{\pi_{d}(d)}{\pi_{A}(m)-\pi_{G}(m)} .
$$

The takeover condition $\tau_{f}^{T O}(\gamma)$ and the preemption condition $\tau_{f}^{P E}(\gamma)$ are illustrated in Figure 3.1(iii). Note that points $\mathrm{T}$ and $\mathrm{P}$ indicate where takeover acquisitions and preemptive acquisitions occur for a given level of foreign capital gains taxation $\tilde{\tau}_{f}$, derived from Figure 3.1(i). The locus associated with takeover condition $\tau_{f}^{T O}(\gamma)$ and the preemption condition $\tau_{f}^{P E}(\gamma)$ is then upward-sloping in the $\gamma-\tau_{f}$ space. Intuitively, at higher complementarities $\gamma$, a higher foreign capital gains taxation $\tau_{f}$ is needed to balance the foreign firm's higher value of obtaining the domestic assets (i.e. to preserve $v_{m l}=v_{d}$ for $l=d, m$ ). The locus for the takeover condition $\tau_{f}^{T O}(\gamma)$ is above the locus of the preemption condition $\tau_{f}^{P O}(\gamma)$ if and only if the complementarities are not too large. ${ }^{23}$ The equilibrium ownership structure involves domestic ownership north-east of the takeover locus $\tau_{f}^{T O}(\gamma)$, indicated as $\mathbf{K}(d)$. Preemptive acquisitions occur southwest of the preemption locus $\tau_{f}^{P O}(\gamma)$, as is indicated by $\mathbf{K}(m)$ and $S^{*}=v_{m m}$. Finally, takeover acquisitions occur for combinations of $\gamma$ and $\tau_{f}$ between the takeover locus $\tau_{f}^{T O}(\gamma)$ and the preemption locus $\tau_{f}^{P O}(\gamma)$, indicated as $\mathbf{K}(m)$ and $S^{*}=v_{d}$.

Inspecting Figure 3.1(iii), we can make the following observations:

\footnotetext{
${ }^{23}$ At point $\mathrm{C}$ in Figure 3.1 (i) $v_{m d}=v_{m m}$. It then follows that $\tau_{f}^{T O}(\gamma)=\tau_{f}^{P E}(\gamma)$ at point $\mathrm{C}$ in Figure 3.1 (iii).
} 
(i) There is no effect of taxes levied in the host country on the equilibrium ownership structure: The domestic capital gains tax $\tau_{h}$ is neutral to the decision of whether to sell, since as noted from (3.1), the reward for selling/not selling is taxed symmetrically. Moreover, since the domestic profit tax $t_{h}$ is paid by all firms, it has a symmetric effect on foreign firms' valuations and the domestic firm's reservation price and hence, does not affect the equilibrium ownership of the domestic assets $\bar{k}$.

(ii) For a given level of the complementarity $\gamma$, a reduction of $\tau_{f}$ can induce foreign acquisitions, since a lower tax for foreign share holders increases foreign firms' valuations of the domestic assets from (3.4) and (3.5). At low level of complementarities, reductions in taxes may even trigger inefficient foreign acquisitions where $\gamma<1$. This can be seen from a vertical movement from Region I to Region III in 3.1(iii). The driving force behind these inefficient acquisitions is the increase in concentration resulting from the acquisition, which becomes less costly to achieve at lower taxation.

(iii) If the complementarity between foreign and domestic assets is sufficiently high, reduced foreign capital gains $\operatorname{tax} \tau_{f}$ can lead to efficient foreign acquisitions where $\gamma>1$. Intuitively, at lower taxation, efficient foreign acquisitions also become less costly as the tax burden is reduced. Thus, lower foreign capital gains taxes can trigger efficient foreign acquisitions, which can be seen from a vertical movement from Region II to Region IV in $3.1($ iii).

Thus, we can state the following proposition:

Proposition 2. If goodwill is not deductible and transfer pricing is not possible, then (i) if the complementarity between foreign and domestic assets is sufficiently low, reduced foreign capital gains tax can lead to inefficient foreign acquisitions, and (ii) if the complementarity between foreign and domestic assets is sufficiently high, reduced foreign capital gains tax can lead to efficient foreign acquisitions.

The existence of these results can also be shown making use of a Linear Quadratic 


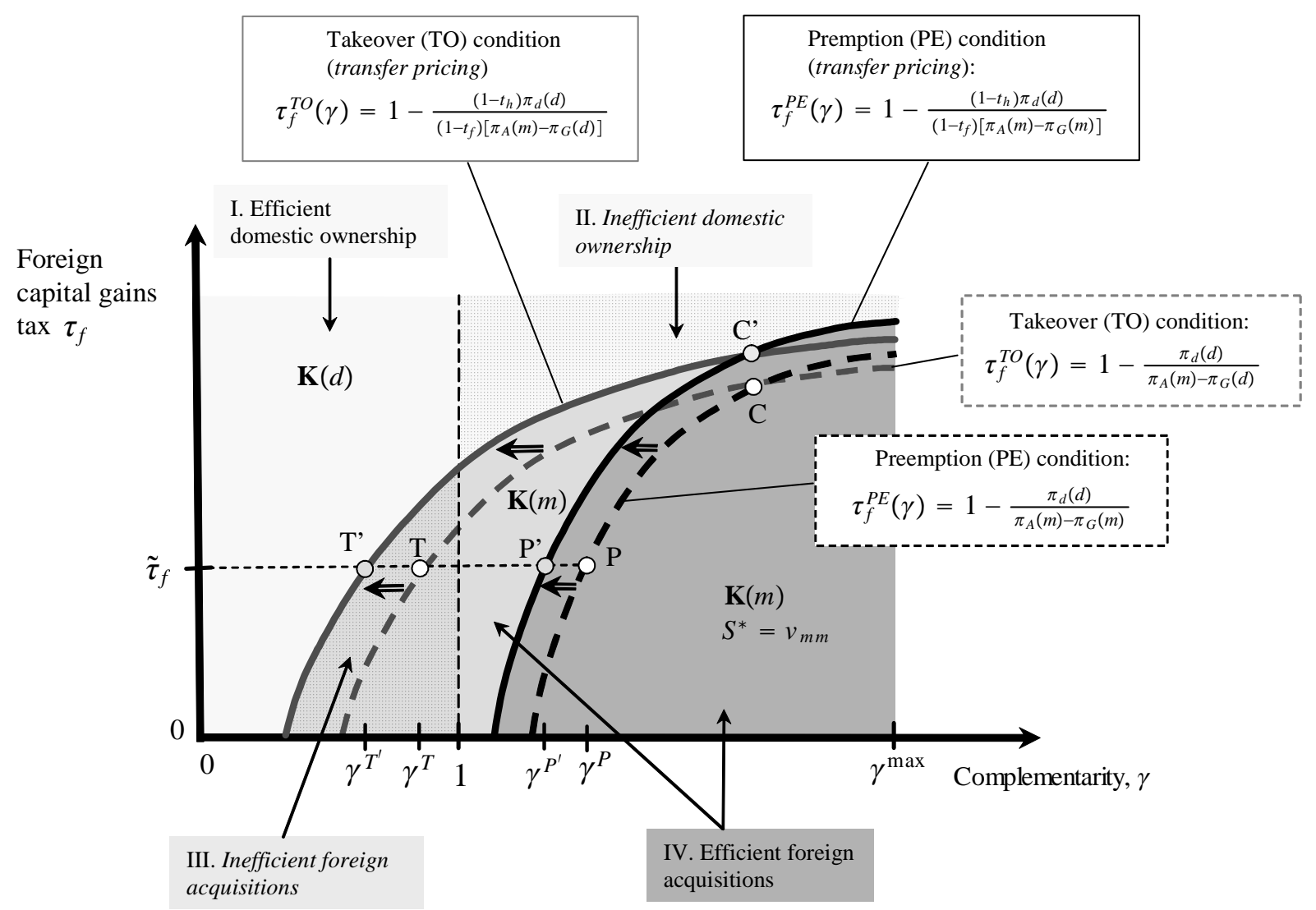

Figure 3.2: The Equilibrium ownership structure under transfer pricing.

Cournot Model described in the Appendix. ${ }^{24}$

\subsection{Goodwill not deductible and transfer pricing is an option}

It is well known that foreign firms can reduce their overall tax burden by shifting profits toward low-tax countries, for example by using transfer pricing techniques. Indeed, Bartelsman and Beetsma (2000) find evidence of tax differences having a significant impact on where incomes are declared. ${ }^{25}$ To capture this, we assume that a foreign owner can use transfer pricing to transfer all profits to a foreign tax haven, where a foreign profit tax, $t_{f}<t_{h}$, is paid. As discussed in Section 2, such transfer pricing is assumed to be risk free and costless.

\footnotetext{
${ }^{24}$ Proofs are available upon request.

25 See also references in World Investment Report (WIR) 1998.
} 
To see how results change under transfer pricing, we need only substitute the foreign profit tax $t_{f}$ for the home profit tax $t_{h}$ into the expressions for foreign firms' valuations (3.4) and (3.5), and thus $v_{m l}=\left(1-\tau_{f}\right)\left(1-t_{f}\right)\left[\pi_{A}(m)-\pi_{G}(l)\right]$ for $l=d, m$. Since firm d's reservation price remains unchanged at $v_{d}=\left(1-t_{h}\right) \pi_{d}(d)$, the takeover condition (3.7) and the preemption condition (3.8) become:

$$
\tau_{f}^{T O}(\gamma)=1-\frac{\left(1-t_{h}\right) \pi_{d}(d)}{\left(1-t_{f}\right)\left[\pi_{A}(m)-\pi_{G}(d)\right]}, \quad \tau_{f}^{P E}(\gamma)=1-\frac{\left(1-t_{h}\right) \pi_{d}(d)}{\left(1-t_{f}\right)\left[\pi_{A}(m)-\pi_{G}(m)\right]}
$$

Comparing (3.9) with (3.7) and (3.8), it follows that both the takeover locus $\tau_{f}^{T O}(\gamma)$ and the preemption locus $\tau_{f}^{P E}(\gamma)$ will shift to the left in Figure 3.1, due to transfer pricing since $t_{f}<t_{h}$ implies that $\frac{\left(1-t_{h}\right)}{\left(1-t_{f}\right)}<1$. This is illustrated in Figure 3.2. Note that points T' and $\mathrm{P}^{\prime}$ indicate that takeover acquisitions and preemptive acquisitions occur at lower complementarities under transfer pricing, since $\gamma^{T^{\prime}}<\gamma^{T}$ and $\gamma^{P^{\prime}}<\gamma^{P}$. Intuitively, as tax evasion occurs through the transfers of profits to a tax haven, complementarities need to be smaller to balance the foreign firms' higher value of obtaining the domestic assets (i.e. to preserve $v_{m l}=v_{d}$ for $\left.l=d, m\right)$. As can be seen in Figure 3.2, this increases Region III where inefficient foreign acquisitions occur, while reducing Region II where inefficient domestic ownership prevails.

We have the following proposition:

Proposition 3. If goodwill is not deductible and transfer pricing is possible, then (i) if the complementarity between foreign and domestic assets is sufficiently low, reduced foreign capital gains tax and reduced foreign profit tax can lead to inefficient foreign acquisitions, and (ii) if the complementarity between foreign and domestic assets is sufficiently high, reduced foreign capital gains tax and reduced foreign profit tax can lead to efficient foreign acquisitions. 


\subsection{Goodwill deductible}

The deductibility of "goodwill" associated with an acquisition, i.e. the part of the acquisition price above the value of deductible assets in the acquired firm, varies between countries and is open to different plausible interpretations. The previous section took the assumption of not allowing goodwill to be deductible. How will the results change if this assumption is relaxed? To explore this, first assume that transfer pricing is not possible and hence, foreign firms pay domestic profits taxes $t_{h}$. Assume that goodwill can be deducted when capital gains taxes are to be paid, but not when profit taxes are to be paid. To derive foreign firm valuations, a foreign firms' net gain from buying firm d's assets is:

$$
\Delta_{m l}(S)=\underbrace{\left(1-\tau_{f}\right)\left[\left(1-t_{h}\right) \pi_{A}(m)-S\right]-S}_{\text {Net profit from acquisition }}-\underbrace{\left(1-\tau_{f}\right)\left(1-t_{h}\right) \pi_{G}(l)}_{\text {Net profit from greenfield entry }},
$$

where $l=d, m$ indicating the alternative ownership of assets $\bar{k}$ when an foreign firm does not obtain these assets and enters greenfield. Once more, define the foreign firm's valuation as $v_{m l} \equiv \max S$, s.t $\Delta_{m l}(S) \geq 0$. Solving for $\Delta_{m l}(S)=0$, foreign firms' valuations $v_{m l}$ are thus $v_{m d}=\left(1-t_{h}\right)\left[\pi_{A}(m)-\pi_{G}(d)\right]$, which is the value of an acquisition given that firm $d$ will not otherwise sell, and $v_{m m}=\left(1-t_{h}\right)\left[\pi_{A}(m)-\pi_{G}(m)\right]$, which is the value of an acquisition, given that a rival foreign firm will otherwise obtains firm d's assets. Note that since firm d's reservation price does not change and thus remains at $v_{d}=\left(1-t_{h}\right) \pi_{d}(d)$, it follows that taxes are completely neutral in this case.

Thus, we can state the following proposition:

Proposition 4. If goodwill is deductible and transfer pricing is not an option, foreign corporate taxes will not affect the pattern of foreign acquisitions.

Under transfer pricing, foreign firms' valuations become $v_{m l}=\left(1-t_{f}\right)\left[\pi_{A}(m)-\pi_{G}(l)\right]$ for $l=d, m$, while the domestic owner's reservation price is $v_{d}=\left(1-t_{h}\right) \pi_{d}(d)$. Using the same method as above, we can state the following proposition: 
Proposition 5. If goodwill is deductible and transfer pricing is possible, then (i) if the complementarity between foreign and domestic assets is sufficiently low, reduced foreign profit tax can lead to inefficient foreign acquisitions, and (ii) if the complementarity between foreign and domestic assets is sufficiently high, reduced foreign profit tax can lead to efficient foreign acquisitions.

\section{Tax revenues}

In the introduction, we noted that capital gains tax revenues could potentially be substantially increased when a foreign acquisition occurs, as illustrated by the example of Ford's acquisition of Volvo in Figure 1.1. In this section, it is shown that a foreign acquisition can indeed increase tax revenues when the complementarities between foreign and domestic assets are high, and that there is a fundamental difference between foreign direct investment in scarce and non-scarce assets concerning the effects on tax revenues.

To this end, add a stage zero to the game where the government chooses among three types of policies towards FDI, considering the impact on tax revenues. Under a restrictive (R) policy, FDI is not allowed, and the domestic monopoly remains intact. Denote the associated ownership structure $\mathbf{K}\left(d^{\mathrm{mon}}\right)^{26}$. Under a discriminatory (D) policy, only greenfield FDI is allowed. The associated ownership structure is then $\mathbf{K}(d)$, where firm d keeps its assets and all foreign firms enter greenfield. Finally, under a liberal (L) policy, both greenfield and acquisition FDI are allowed and hence, in addition to the ownership structures $\mathbf{K}(d)$, the ownership structure $\mathbf{K}(m)$ may arise, where the domestic owner sells its assets in stage 1 to one of the foreign firms and remaining foreign firms enter greenfield. Note that while our discussion here assumes that government policy shapes the FDI pattern, we could also interpret these policies as situations where only certain types of entry modes are available. For instance, in some industries, no valuable targets might be present and greenfield entry might be the only possible way of entering. An alternative

\footnotetext{
${ }^{26} \mathbf{K}\left(d^{\text {mon }}\right)=\left(\bar{k}+\kappa_{d}^{*}, 0, \ldots, 0\right)$. In this case, the domestic firm retains its monopoly and holds assets $\bar{k}+\kappa_{d}^{*}$.
} 
interpretation is thus that nature chooses the type of industry in stage zero.

To proceed, we assume that foreign firms cannot deduct goodwill while transfer pricing is possible, i.e. we base the analysis on the case studied in Section 3.2. This enables us to illustrate the main mechanisms in a convenient way. In particular, it enables us to abstract from tax payments by greenfield entrants to focus on the direct effect of the foreign acquisition on domestic tax revenues. We discuss the effects on tax revenues of different treatments of goodwill deductions and transfer pricing in the end of the ensuing sections.

\subsection{Tax revenues and entry mode}

Let us first compare the collected tax revenues when only greenfield takes place under the D-policy with the collected taxes when no FDI takes place under the R-policy. Tax revenues under the R-policy are simply those from taxing the monopoly twice. This tax revenue is $T^{R}=\left[t_{h}+\tau_{h}\left(1-t_{h}\right)\right] \pi_{d}\left(d^{\text {mon }}\right)$. Tax revenues under the D-policy are $T^{D}=\left[t_{h}+\tau_{h}\left(1-t_{h}\right)\right] \pi_{d}(d)$, since $\pi_{d}(d)$ is the domestic firm's profit under greenfield entry by foreign firms and since foreign firms fully evade taxes in the host country. The tax revenues $T^{R}$ and $T^{D}$ are illustrated as horizontal lines in Figure 4.1 (iii) since from definition 1 , tax revenues $T^{R}$ and $T^{D}$ do not depend on $\gamma$. We then have:

$$
T^{D}-T^{R}=\left[t_{h}^{c}\left(1-t_{h}\right)+t_{h}\right] \underbrace{\left[\pi_{d}(d)-\pi_{d}\left(d^{\mathrm{mon}}\right)\right]}_{(-)}<0
$$

where we make the assumption that the loss of monopoly power reduces firm d's product market profit, $\pi_{d}(d)<\pi_{d}\left(d^{\text {mon }}\right)$.

Consequently, we have derived the following result:

Lemma 1. If goodwill is not deductible, foreign firms can use transfer pricing and if foreign firms only enter greenfield, tax revenues will be lower than if the domestic monopoly remained, i.e. $T^{R}>T^{D}$. 
Intuitively, when FDI only takes place through greenfield entry, tax revenues are reduced from FDI since the foreign entrants evade taxes and the domestic firm's taxable profit is reduced.

Let us now also consider the L-policy where also a foreign acquisition takes place. In Figures 4.1 (i) and 4.1 (ii), we derive the equilibrium ownership structure (EOS) varying the size of the complementarities $\gamma$. Under transfer pricing, note that takeover acquisitions becomes profitable at T', whereas preemptive acquisitions are profitable at P'. Hence, for low complementarities $\gamma \in\left(0, \gamma^{T^{\prime}}\right)$, no acquisition takes place, and tax revenues are hence identical under the L- and D-policies. When $\gamma \in\left[\gamma^{T^{\prime}}, \gamma^{P^{\prime}}\right)$, a takeover acquisitions occurs and the acquisition price is $S^{*}=v_{d}=\left(1-t_{h}\right) \pi_{d}(d)$. The corresponding tax revenues are thus $T^{L}=\tau_{h} v_{d}=\tau_{h}\left(1-t_{h}\right) \pi_{d}(d)$. As illustrated in Figure 4.1 (iii), in this interval, the L-policy may not only induce inefficient acquisitions (for which $\gamma<1$ ), it also generates the lowest tax revenues since the foreign acquirer uses transfer pricing to avoid paying profit taxes in the host country, which is illustrated by the downward shift in the $T^{L}$ curve in Figure 4.1 (iii) at $\gamma^{T}$.

However, at high complementarities $\gamma \in\left[\gamma^{P^{\prime}}, \gamma^{\max }\right)$, a preemptive acquisition will occur and the acquisition price is driven up to $S^{*}=v_{m m}=\left(1-\tau_{f}\right)\left(1-t_{f}\right)\left[\pi_{A}(m)-\pi_{G}(m)\right]$. The corresponding tax revenues in this case are $T^{L}=\tau_{h} v_{m m}$. In contrast, in this interval, tax revenues may be maximized by allowing for foreign acquisition under the L-policy since the sales price might and the corresponding capital gains tax revenues might then be so large to compensate for the loss of double taxation of the domestic monopoly profit $\pi_{d}\left(d^{\text {mon }}\right)$. This is illustrated by the upward slope of the $T^{L}$ curve in Figure 4.1 (iii) at $\gamma^{P^{\prime}}$ and the $T^{L}$ curve being above the $T^{R}$ curve at $\gamma>\hat{\gamma}^{L R}$.

We have thus derived the following result:

Proposition 6. (i) When a takeover acquisition occurs for medium complementarities $\gamma \in\left[\gamma^{T^{\prime}}, \gamma^{\max }\right]$, the L-policy allowing both acquisitions and greenfield FDI leads to the lowest tax revenues, $T^{R}>T^{D}>T^{L}$. (ii) When a preemptive acquisition occurs for suffi- 


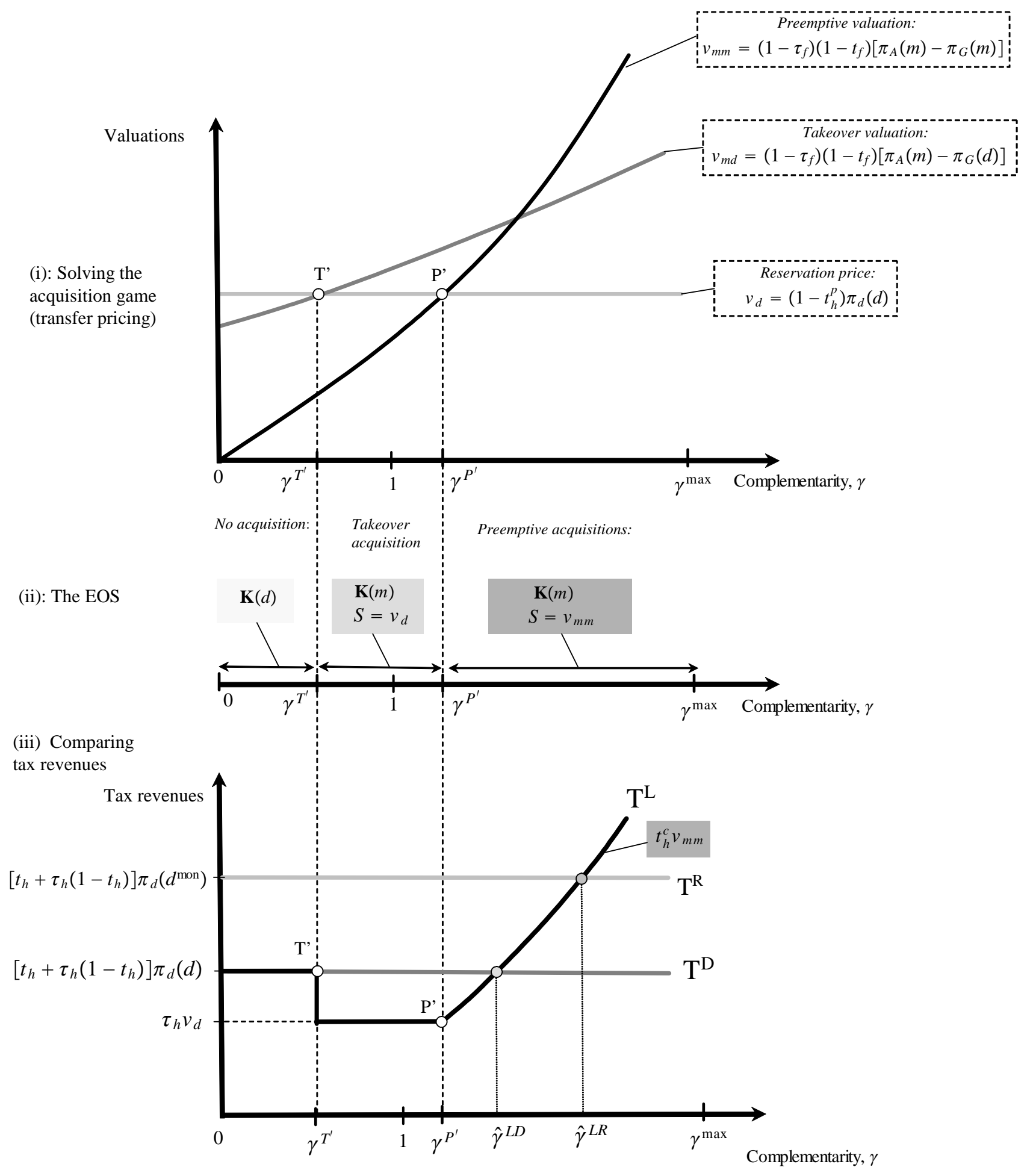

Figure 4.1: Tax revenues and government policy under transfer pricing. 
ciently high complementarities $\gamma>\hat{\gamma}^{L R} \geq \gamma^{P^{\prime}}$, the L-policy allowing both acquisition and greenfield FDI, leads to the highest tax revenues, $T^{L}>T^{R}>T^{D}$.

The proposition illustrates that foreign acquisitions may indeed reduce tax revenues when foreign firms evade taxes. However, given that the target's complementarities and efficiency gains are sufficiently large, the proposition also illustrates that allowing both types of entry might generate higher tax revenues than restricting foreign entry, despite the tax evasion by the foreign firms. Due to fierce bidding competition between the foreign firms over highly complementary domestic assets, all benefits from the acquisition - including the evaded taxes - are then competed away and accrue to the domestic seller. Hence, by taxing the increased capital gains of the selling domestic owner, the lost profit taxes are compensated, and if the increase in capital gains for the domestic seller is sufficiently large, the tax revenues will be higher when the acquisition takes place.

How would the results then change if goodwill is deductible and transfer pricing is not an option? More generally, when preemptive acquisitions occur for sufficiently high synergies, the bidding competition over strategically valuable assets will lead to increased taxable capital gains from the domestic seller. Indeed, this holds regardless of the tax system as long as the host country taxes domestic shareholders. In particular, maintaining the assumption of no goodwill deduction while relaxing the assumption of transfer pricing, will strengthen the result that tax revenues can increase from allowing foreign acquisitions. This follows from the fact that a foreign acquisition will in this environment take place if and only if aggregate industry profit increases, which in turn implies that aggregate taxable profits will increase under the L-policy. Proof of these statements based on the Linear Quadratic model is available upon request.

\subsection{Tax revenues and tax competition}

Let us also illustrate the effects of tax competition on tax revenues maintaining the assumption of transfer pricing. To this end, consider the case where $\gamma \in\left[\gamma^{P^{\prime}}, \gamma^{\max }\right)$, and a preemp- 
tive acquisition occurs at an acquisition price $S^{*}=v_{m m}=\left(1-\tau_{f}\right)\left(1-t_{f}\right)\left[\pi_{A}(m)-\pi_{G}(m)\right]$. Consequently, we can then derive the following result:

$$
\left\{\begin{array}{c}
\frac{d T^{L}}{d \tau_{f}}=-\tau_{h}\left(1-t_{f}\right)\left[\pi_{A}(m)-\pi_{G}(m)\right]<0 \\
\frac{d T^{L}}{d t_{f}}=-\tau_{h}\left(1-\tau_{f}\right)\left[\pi_{A}(m)-\pi_{G}(m)\right]<0
\end{array} .\right.
$$

Thus, we have derived the following proposition:

Proposition 7. If goodwill is not deductible and transfer pricing is possible, then a host country's tax revenues might increase when another country reduces its capital gains tax and/or profit tax, since the acquisition price of its domestic target firms increases and thus, also the tax revenues.

Moreover, it directly follows that as long goodwill is not deductible, reduced foreign capital taxes can increase domestic tax revenues independent of whether transfer pricing is an option. As long as transfer pricing is an option, reduced foreign profit taxes can increase domestic tax revenues independent of whether deduction of goodwill is an option.

On a final note, we have assumed that no re-location of production takes place from country $\mathrm{H}$ under tax competition. Even when relaxing this assumption, it is true that tax revenues may increase from an acquisition. To see this, assume that foreign firms will serve the market in country $\mathrm{H}$ from the foreign tax haven (or from another location with low production costs and access to low taxes). Then, note that the acquisition price is still $S^{*}=v_{m m}=\left(1-\tau_{f}\right)\left(1-t_{f}\right)\left[\pi_{A}(m)-\pi_{G}(m)\right]$. Thus, if the services of assets $\bar{k}$ can be relocated $^{27}$ and complementarities are large, tax revenues from capital gains taxes from a foreign acquisition may still be sizable even if the foreign acquirer moves production outside of country $\mathrm{H}^{28}$

\footnotetext{
${ }^{27}$ The assets $\bar{k}$ could, for instance, be a trade market or a well-known product, or a unique technology.

${ }^{28}$ The results derived here would be also valid in a setting where firm $d$ and the $M$ foreign firms would be active on a world market. In such a setting, firm $d$ would have the decision to sell to one of the foreign competitors, or remain as an independent competitor. This setting would correspond more closely to the acquisition of the Swedish car producer Volvo, discussed in the introduction, for which the majority of customers are located outside Sweden.
} 


\section{Concluding remarks}

We find that reduced foreign corporate taxes can lead to inefficient foreign acquisition if complementarities between foreign and domestic assets are low and to efficient foreign acquisitions if such complementarities are high. Reduced foreign taxes can then stimulate a domestic industry if combined with a well functioning merger law blocking foreign acquisitions mainly driven by market power.

Further, it is well known that foreign entry by foreign firms may lead to rent shifts from domestic to foreign owners which, in turn, may reduce the tax revenues for the domestic country. However, it is shown in this paper that if foreign entry takes place through the acquisition of sufficiently scarce domestic assets, domestic tax revenues can increase. The reason is that in the bidding competition between the foreign firms over the scarce domestic assets, the benefits from the acquisition, including tax advantages and evaded taxes, are competed away and captured by the domestic seller which, in turn, pays capital gains tax on the proceeds. Consequently, the paper suggests that one important measure for mitigating the effects of tax evasion by foreign firms is to ensure that there is competition between foreign firms to enter the domestic market. Otherwise, a dominating foreign entrant may use its bargaining power to enter the domestic market, without creating rents for domestic scarce sector-specific assets. An implication for tax authorities is then that the monitoring of capital gains acts as a substitute for the monitoring of profit shifting activities.

This paper demonstrates that some aspects of foreign acquisitions can be more complex than commonly perceived. Our results show that quite technical issues in the tax code, such as the treatment of goodwill deductibility, can have important effects on the pattern of foreign acquisitions, productive efficiency and tax revenues. It therefore seems reasonable to take into account these aspects of the corporate tax code in the recent efforts to harmonize various aspects of European takeover regulation. ${ }^{29}$

\footnotetext{
${ }^{29}$ See e.g. Berglöf and Burkart (2003).
} 
There are several interesting avenues for future research. Endogenizing taxes in this framework would probably lead to new interesting results on tax competition, among other things. Studying the long run effects on the investment pattern in this environment seems also fruitful. An interesting empirical challenge would be to investigate how responsive asset prices are to differences in tax rates (and levels of enforcement of these taxes) across countries.

\section{A. Appendix:}

Here, we derive the EOS relaxing Assumption A2 in the text. The EOS is shown in table A.1 and proved below.

Table A.1: The equilibrium ownership structure and the acquisition price under the Lpolicy.

\begin{tabular}{cccc}
\hline \hline Ineq: & Definition: & $\begin{array}{c}\text { Ownership } \\
\text { structure: }\end{array}$ & $\begin{array}{c}\text { Acquisition } \\
\text { price } S:\end{array}$ \\
\hline$I 1:$ & $v_{m m}>v_{m d}>v_{d}$ & $\mathbf{K}(m)$ & $v_{m m}$ \\
$I 2:$ & $v_{m m}>v_{d}>v_{m d}$ & $\mathbf{K}(m)$ or $\mathbf{K}(d)$ & $v_{m m}$ \\
$I 3:$ & $v_{m d}>v_{m m}>v_{d}$ & $\mathbf{K}(m)$ & $v_{m m}$ \\
$I 4:$ & $v_{m d}>v_{d}>v_{m m}$ & $\mathbf{K}(m)$ & $v_{d}$ \\
$I 5:$ & $v_{d}>v_{m m}>v_{m d}$ & $\mathbf{K}(d)$ &. \\
$I 6:$ & $v_{d}>v_{m d}>v_{m m}$ & $\mathbf{K}(d)$ &. \\
\hline \hline
\end{tabular}

\section{A.1. Proof of Table A.1}

First, note that $b_{i} \geq \max v_{m l}, l=\{\mathrm{d}, \mathrm{m}\}$ is a weakly dominated strategy, since no foreign firm will post a bid equal to or above its maximum valuation of obtaining the assets, and 
that firm $d$ will accept a bid in stage 2 , iff $b_{i}>v_{d}$.

Inequality $\mathbf{I}$ Consider the equilibrium candidate $\mathbf{b}^{*}=\left(b_{1}^{*}, b_{2}^{*}, \ldots\right.$, yes $)$. Let us assume that foreign firm $w \neq d$ is the foreign firm that has posted the highest bid and obtains the assets and firm $s \neq d$ the foreign firm with the second highest bid.

Then, $b_{w}^{*} \geq v_{m m}$ is a weakly dominated strategy. $b_{w}^{*}<v_{m m}-\varepsilon$ is not an equilibrium, since firm $j \neq w, d$ then benefits from deviating to $b_{j}=b_{w}^{*}+\varepsilon$, since it will then obtain the assets and pay a price lower than its valuation of obtaining them. If $b_{w}^{*}=v_{m m}-\varepsilon$, and $b_{s}^{*} \in\left[v_{m m}-\varepsilon, v_{m m}-2 \varepsilon\right]$, then no foreign firm has an incentive to deviate. By deviating to $n o$, firm $d$ 's payoff decreases since it foregoes a selling price exceeding its valuation, $v_{d}$. Accordingly, firm $d$ has no incentive to deviate and thus, $\mathbf{b}^{*}$ is a Nash equilibrium.

Let $\mathbf{b}=\left(b_{1},,, b_{m}, n o\right)$ be a Nash equilibrium. Let foreign firm $h$ be the foreign firm with the highest bid. Firm $d$ will then say no iff $b_{h} \leq v_{d}$. But foreign firm $j \neq d$ will have the incentive to deviate to $b^{\prime}=v_{d}+\varepsilon$ in period 1 , since $v_{m d}>v_{d}$. This contradicts the assumption that $\mathbf{b}$ is a Nash equilibrium.

Inequality $\mathbf{I} 2$ Consider the equilibrium candidate $\mathbf{b}^{*}=\left(b_{1}^{*}, b_{2}^{*}, \ldots, y\right)$. Then, $b_{w}^{*} \geq v_{i j}$ is a weakly dominated strategy. $b_{w}^{*}<v_{i j}-\varepsilon$ is not an equilibrium since firm $j \neq w, d$ then benefits from deviating to $b_{j}=b_{w}^{*}+\varepsilon$, since it will then obtain the assets and pay a price lower than its valuation of obtaining them. If $b_{w}^{*}=v_{m m}-\varepsilon$, and $b_{s}^{*} \in\left[v_{m m}-\varepsilon, v_{m m}-2 \varepsilon\right]$, then no foreign firm has an incentive to deviate. By deviating to no, firm d's payoff decreases since it foregoes a selling price exceeding its valuation, $v_{d}$. Accordingly, firm $d$ has no incentive to deviate and thus, $b^{*}$ is a Nash equilibrium.

Consider the equilibrium candidate $b^{* *}=\left(b_{1}^{* *}, b_{2}^{* *}, \ldots, n o\right)$. Then, $b_{w}^{*} \geq v_{m d}$ is not an equilibrium, since firm $d$ would then benefit by deviating to yes. If $b_{w}^{*} \leq v_{d}$, then no foreign firm has an incentive to deviate. By deviating to yes, firm d's payoff decreases, since it then sells its assets at a price below its valuation, $v_{d}$. Firm $d$ has no incentive to deviate and thus, $b^{* *}$ is a Nash equilibrium. 
Inequality I3 Consider the equilibrium candidate $b^{*}=\left(b_{1}^{*}, b_{2}^{*}, \ldots\right.$, yes $)$. Then, $b_{w}^{*} \geq v_{m m}$ is a weakly dominated strategy. $b_{w}^{*}<v_{m m}-\varepsilon$ is not an equilibrium, since firm $j \neq w, d$ then benefits from deviating to $b_{j}=b_{w}^{*}+\varepsilon$, since it will then obtain the assets and pay a price lower than its valuation of obtaining them. If $b_{w}^{*}=v_{m m}-\varepsilon$, and $b_{s}^{*} \in\left[v_{m m}-\varepsilon, v_{m m}-2 \varepsilon\right]$, then no foreign firm has an incentive to deviate. By deviating to no, firm d's payoff decreases, since it foregoes a selling price exceeding its valuation, $v_{d}$. Accordingly, firm $d$ has no incentive to deviate and thus, $b^{*}$ is a Nash equilibrium.

Let $b=\left(b_{1}, \ldots, b_{M}, n o\right)$ be a Nash equilibrium. Firm $d$ will then say no iff $b_{h} \leq v_{d}$. But foreign firm $j \neq d$ will then have the incentive to deviate to $b^{\prime}=v_{d}+\varepsilon$ in stage 1 , since $v_{m d}>v_{d}$. This contradicts the assumption that $\mathbf{b}$ is a Nash equilibrium.

Inequality $\mathbf{I} 4$ Consider the equilibrium candidate $\mathbf{b}^{*}=\left(b_{1}^{*}, b_{2}^{*}, \ldots\right.$, yes $)$. Then, $b_{w}^{*}>v_{d}$ is not an equilibrium since firm $w$ would then benefit from deviating to $b_{w}=v_{d}$. $b_{w}^{*}<v_{d}$ is not an equilibrium, since firm $d$ would then not accept any bid. If $b_{w}^{*}=v_{d}-\varepsilon$, then firm $w$ has no incentive to deviate. By deviating to $b_{j}^{\prime} \leq b_{w}^{*}$, firm $j$ 's, $j \neq w, d$, payoff does not change. By deviating to $b_{j}^{\prime}>b_{w}^{*}$, firm $j$ 's payoff decreases since it must pay a price above its willingness to pay $v_{m m}$. Accordingly, firm $j$ has no incentive to deviate. By deviating to $n o$, firm $d$ 's payoff decreases since it foregoes a selling price above its valuation $v_{d}$. Accordingly, firm $d$ has no incentive to deviate and thus, $\mathbf{b}^{*}$ is a Nash equilibrium.

Let $\mathbf{b}=\left(b_{1},,, b_{m}, y e s\right)$ be a Nash equilibrium. If $b_{w} \geq v_{m m}$, then firm $w$ will have the incentive to deviate to $b^{\prime}=b_{w}-\varepsilon$. If $b_{w}<v_{m m}$, then firm $d$ will have the incentive to deviate to no, which contradicts the assumption that $\mathbf{b}$ is a Nash equilibrium.

Let $\mathbf{b}=\left(b_{1}, \ldots, b_{m}, n o\right)$ be a Nash equilibrium. Firm $d$ will then say no iff $b_{h} \leq v_{d}$. But foreign firm $j \neq d$ will have the incentive to deviate to $b^{\prime}=v_{d}+\varepsilon$ in stage 1 since $v_{m d}>v_{d}$, which contradicts the assumption that $\mathbf{b}$ is a Nash equilibrium.

Inequalities $\mathbf{I 5}$ or $\mathbf{I} 6$ Consider the equilibrium candidate $\mathbf{b}^{*}=\left(b_{1}^{*}, b_{2}^{*}, \ldots, n o\right)$, where $b_{i}^{*}<v_{d} \forall i \in M$. It then follows directly that no firm has an incentive to deviate and thus, 
$\mathbf{b}^{*}$ is a Nash equilibrium.

Then, note that firm $d$ will accept a bid iff $b_{i} \geq v_{d}$. But $b_{i} \geq v_{d}$ is a weakly dominating bid in these intervals, since $v_{d}>\max \left\{v_{m m}, v_{m d}\right\}$. Thus, the assets will not be sold in these intervals.

\section{B. The linear quadratic Cournot model}

Let the oligopoly interaction in period three be described by Cournot competition in homogenous goods. The profit for firm $i$ can be written (omitting function arguments on the right-hand side) $\left(1-\tau_{r}\right)\left(1-t_{r}\right) \pi_{i}(\mathbf{q}, \boldsymbol{\kappa}, l)=\left(1-\tau_{r}\right)\left(1-t_{r}\right)\left[\left(P-c_{i}\right) q_{i}-\frac{\mu \kappa_{i}^{2}}{2}\right]$, where we assume costs to be quadratic in new assets, $\kappa_{i}$, which we henceforth refer to as new capital. Investments in new capital in stage 2 reduce a firm's marginal cost in a linear fashion, $c_{i}=\bar{c}_{i}-\theta \kappa_{i}$, where $\theta$ is a positive constant ${ }^{30}$

Making a distinction between firm types, we also have:

$$
\bar{c}_{G}=c, \quad \bar{c}_{A}=c-\gamma \bar{k}, \quad \bar{c}_{d}=c-\bar{k} .
$$

Hence, we assume existing assets $\bar{k}$ and new assets $\kappa_{i}$ to be imperfect substitutes. An acquisition of $\bar{k}$ may, as discussed in section 2.2, provide knowledge of the market, or provide access to an existing distribution network, thereby providing assets distinct from new investments $\kappa_{i}$, which provide a capacity to produce. This is modelled by assuming that gaining possession of the domestic assets $\bar{k}$ in stage one alters the intercept term $\bar{c}_{i}$ in (B.1). Note also that the complementarity parameter $\gamma$ in (B.1) shows the effect of adding foreign firms' firm-specific assets to domestic assets $\bar{k}$. Let the inverse demand in

${ }^{30}$ For simplicity, we assume all firms to share the same investment technology, $\theta$ and $\mu$. Asymmetries between firms are captured by the intercept term, $\bar{c}_{i}$, which measures the impact on firm $i$ 's absolute efficiency level of the possession of all other assets (such as firm-specific assets or acquired assets) prior to investment in new assets, $\kappa_{i}$, in stage 2. Assuming that asymmetries between firms enter through the intercept term $\bar{c}_{i}$ in the marginal cost $c_{i}=\bar{c}_{i}-\theta \kappa_{i}$ simplifies the calculations. Alternatively, we could assume that firms differ in their investment costs for new investments $\left(\mu_{i}\right)$, or in how efficiently marginal costs can be reduced by new investments $\left(\theta_{i}\right)$. Qualitatively, this yields similar results. 
the product market be given by $P=a-\frac{1}{s} \sum_{i=1}^{N} q_{i}$, where $a>0$ is a demand parameter, $s$ may be interpreted as the size of the market, $N$ is the total number of firms on the market, i.e. $N(m)=M, N(d)=M+1, N\left(d^{m o n}\right)=1$ and $q_{i}$ is the quantity supplied by firm $i$. The game is solved backwards.

In period three, firm $i$ maximizes the net profits $\left(1-\tau_{r}\right)\left(1-t_{r}\right) \pi_{i}(\mathbf{x}, \boldsymbol{\kappa}, l) .(2.1)$ then take the form $\frac{\partial \pi_{i}(\boldsymbol{\kappa}, l)}{\partial q_{i}}=P-c_{i}-q_{i}=0$, where we note that taxes are not distortionary. In period two, firm $i$ invests in new capital, $\kappa_{i}$, taking the optimal quantities $\mathbf{q}^{*}(\boldsymbol{\kappa}, l)$ into account. Maximizing the reduced net profits $\left(1-\tau_{r}\right)\left(1-t_{r}\right) \pi_{i}(\boldsymbol{\kappa}, l),(2.2)$ then take the form $\frac{d \pi_{i}}{d \kappa_{i}}=\frac{\partial \pi_{i}}{\partial \kappa_{i}}+\sum_{j \neq i}^{N} \frac{\partial \pi_{i}}{\partial q_{j}} \frac{d q_{j}}{d \kappa_{i}}=0$, where again taxes are not distortionary and where it can be shown that optimal investments are given from $\kappa_{i}^{*}(l)=\frac{\theta}{\mu} q_{i}^{*} \frac{2 N}{N+1} \cdot{ }^{31}$ We can then solve the Nash equilibrium in new investments $\boldsymbol{\kappa}^{*}(l)$ and its associated Nash equilibrium in quantities $\mathbf{q}^{*}(l)$, and then form the reduced-form profits for each type of firm $\pi_{h}(l), h=$ $\{A, G, D\}$. It can be shown that these profits take the form $\pi_{h}(l)=\frac{1}{s}\left(q_{h}^{*}(l)\right)^{2}\left[1-\frac{2 \eta}{9}\right]$. Define $\Phi(l)=(1+N(l)-2 N(l) \eta)\left(1+2 N(l)+N(l)^{2}-2 N(l) \eta\right), \Omega(l)=\Lambda(1+N(l)-2 N(l) \eta)$ and $\Gamma(l)=(1+N(l)-2 \eta)$. Then, we can write $q_{A}^{*}(m)=\frac{s(N(m)+1)\left[\Omega(m)-N(m) \bar{c}_{A} \Gamma(m)\right]}{\Phi(m)}$, $q_{G}^{*}(m)=\frac{s(N(m)+1)\left[\Omega(m)+\bar{c}_{A}(N(m)+1)\right]}{\Phi(m)}, \quad q_{d}^{*}(d)=\frac{s(N(d)+1)\left[\Omega(d)-N(d) \bar{c}_{d} \Gamma(d)\right]}{\Phi(d)}$ and, finally, $q_{G}^{*}(d)=$ $\frac{s(N(d)+1)\left[\Omega(d)+\bar{c}_{d}(N(d)+1)\right]}{\Phi(d)}$. Finally, the reduced form profits net of taxes $\left(1-\tau_{r}\right)\left(1-t_{r}\right) \pi_{h}(l)$ can be inserted into valuations $v_{m m}, v_{m d}$ and the domestic firm's reservation price $v_{d}$ to solve the acquisition game in stage 1, and determine the equilibrium ownership structure, $\mathbf{K}(l)$ for the specific assumptions made on the tax system.

\section{References}

[1] Andrade, G., M. Mitchell, and E. Stafford (2001), "New Evidence and Perspectives on Mergers", Journal of Economic Perspectives 15, 103-120.

\footnotetext{
${ }^{31}$ Note also that investments $\kappa_{i}$ do not go to zero when the number of firms on the market reach infinity, which means that profits never go to zero.
} 
[2] Auerbach, A and K Hassett (1993), "Taxation and Foreign Direct Investment in the United States: A Reconsideration of the Evidence", in Giovanni, A, G Hubbard, and J Slemrod (eds) Studies in International Taxation, The University of Chicago Press, Chicago.

[3] Bartelsman, E and Beetsma, R., 2000, Why Pay More? Corporate Tax Avoidance through Transfer Pricing in OECD Countries, CEPR Discussion Paper No. 2543.

[4] Berglöf, E and M Burkart (2003), "European Takeover Regulation", Economic Policy, 36, 171-213.

[5] Bertrand, O. and Zitouna, H., 2006, "Trade Liberalization and Industrial Restructuring: the role of Cross-Border Mergers and Acquisitions", Journal of Economics and Management Strategy, Forthcoming.

[6] Caves, R.E., 1996. Multinational Enterprise and Economic Analysis. 2nd edition, (Cambridge University Press, Cambridge and New York).

[7] Cebenoyan, A. S., G. J. Papaioannou, and N.G. Travlos, 1992, "Foreign takeover activity in the U.S. and wealth effects on target firm shareholders", Financial Management, Autumn, 58-68.

[8] Davies, R. B., 2004, "Tax treaties and foreign direct investments: potential versus performance", International Tax and Public Finance, 11, 775-802.

[9] Dewenter, K.L., 1995, "Does the market react differently to domestic and foreign takeover announcements? Evidence from the U.S. chemical and retail industries, Journal of Financial Economics, 37, 421-441.

[10] Falvey, R., 1998, "Mergers in open economies, "The World Economy, 21, 1061-1076.

[11] Fumagalli, C., 2003, "On the welfare effects of competition for foreign direct investments", European Economic Review, 47, 963-983. 
[12] Harris, R. S. and D. Ravenscraft, 1991, "The Role of Acquisitions in Foreign Direct Investment: Evidence from the U.S. Stock Market,", Journal of Finance, Vol XLVI, NO. $3,825-845$.

[13] Haufler, A. and Schjelderup, G., "Corporate tax systems and cross country profit shifting" Oxford Economics Papers , 52, 306-325.

[14] Haufler, A and Wooton, I, 1999, "Country size and tax competition for foreign direct investments," Journal of Public Economics, 71 (1), 121-139.

[15] Head K, and J. Reis, 1997, "International Mergers and Welfare under Decentralized Competition Policy", Canadian Journal of Economics v30, n4: 1104-23.

[16] Henrekson, M. and Jakobsson, U., 2003, "The Transformation of Ownership Policy and Structure in Sweden: Convergence towards the Anglo-Saxon Model?", New Political Economy, Vol. 8, No. 1.

[17] Horn, H. and L. Persson, 2001, "The Equilibrium Ownership of an International Oligopoly," Journal of International Economics, Vol. 53, No. 2.

[18] Kant, C, 1990, "Multinational firms and government revenues," Journal of Public Economics, 42, 135-147.

[19] Klimenko M. and Saggi K., 2005, "Technical compatibility and the mode of foreign entry with network externalities, Mimeo Georgia Institute of Technology, Atlanta.

[20] Leahy, D. and P. Neary, 1997, "Public policy towards R\&D in oligopolistic industries," American Economic Review, 87:4, 642-662.

[21] Lodin, S-O, Lindecrona, G., Melz, P, and Silfverberg, C., Inkomsskatt- en läro- och handbok i skatterätt, 2001, Studentlitteratur, Lund.

[22] Lommerud, K.E., Straume O.R. and Sorgard, L., 2004, "National versus international mergers in unionized oligopoly," Forthcoming RAND Journal of Economics. 
[23] Markusen, J. R., 1995, The Boundaries of Multinational Enterprises and the Theory of International Trade, Journal of Economic Perspective 9, 169-189.

[24] Mattoo A., Olarrega M., and Saggi K., 2004, "Mode of foreign entry, technology transfers, and FDI policy, Journal of Development Economics, 75, 95-111.

[25] Navaretti, G. B. and A. J. Venables, 2004, Multinational Firms in the World Economy, Princeton University Press, Princeton and Oxford.

[26] Neary, J. P, 2002 "Foreign competition and wage inequality", Review of International Economics, 10:4, 680-693.

[27] Neary, J. P., 2003, "foreign mergers as instruments of comparative advantage," Mimeo, University College Dublin.

[28] Nielsen, S., Raimondos-Möller, P., and G. Schjelderup, 2005, Centralized vs. Decentralized Multinationals and Taxes, CESifo Working Paper Series No. 1586.

[29] Norbäck, P. J. and Persson, L., 2005a, "Privatization Policy in an International Oligopoly," Economica,forthcoming.

[30] Norbäck, P. J. and Persson, L., 2005b, "Investment Liberalization-Why a restrictive foreign merger policy can be counterproductive, IUI Working papers series No. 644 .

[31] Raimondos-Moller, P. and Scharf, K., 2002, "Transfer pricing rules and competing governments", Oxford Economics Papers, 54, 230-246.

[32] Saggi, K. and H.M. Yildiz, 2005, "On the international linkages between trade and merger policies", forthcoming, Review of International Economics.

[33] Sundin, A and S-I Sundqvist (1998), Ägarna och makten i svenska börsbolag [Ownership and Power among Swedish Public Firms], Dagens Nyheter, Stockholm.

[34] Sørensen, P. B., 1995, "Changing views of Corporate Income Tax", National Tax Journal, 48 (2), 279-294. 
[35] UNCTAD, 1998, World Investment Report, Geneva.

[36] Wildasin, W., and Wilson, J.,D., 1991, "Theoretical issues in local public economics," Regional Science and Urban Economics, 21, 317-331. 